

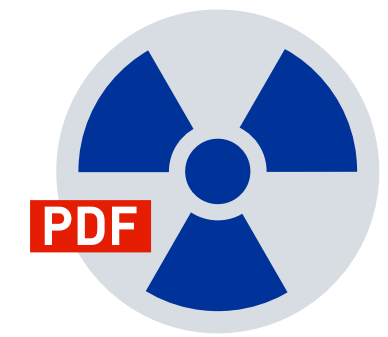

\section{REALOBJECTS PDFreactor $^{\oplus}$}

\section{Evaluation Version}

This PDF document was created by an evaluation version of RealObjects PDFreactor 10.2.10722. The evaluation version is fully functional, but includes this information page. It must not be used for production purposes. The information page and all other evaluation notices must not be removed from the PDF file.

NOTE: Conversions in evaluation mode might be slower and the results might have a larger file size than in production mode.

\section{Buy PDFreactor}

PDFreactor has detected 4 CPU cores, which means you need 1 license pack to use PDFreactor.

To buy a PDFreactor license follow this link:

\section{Buy PDFreactor online}

\section{About PDFreactor}

RealObjects PDFreactor is a powerful formatting processor for converting HTML and XML documents into PDF. It uses Cascading Style Sheets (CSS) to define page layout and styles. The server-side tool enables a great variety of applications in the fields of ERP, eCommerce and Electronic Publishing.

PDFreactor supports HTML5, CSS3 and JavaScript.

It allows you to dynamically generate PDF documents such as invoices, delivery notes and shipping documents on-the-fly. PDFreactor allows you to easily add server-based PDF generation functionality to your application or service. Since PDFreactor runs on a server, the end-user in general does not need any software other than a PDF viewer.

For more information visit www.pdfreactor.com 


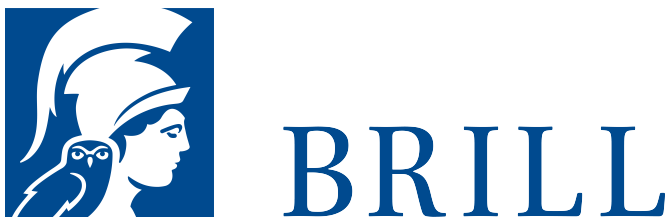

\section{Destruction of Cultural Heritage in 19th- century France}

Old Stones versus Modern Identities

Author: Michael Greenhalgh

Destruction of Cultural Heritage in 1gth Century France examines the fate of the building stock and prominent ruins of France (especially Roman survivals) in the 19th century, supported by contemporary documentation and archives, largely provided through the publications of scholarly societies. The book describes the enormous extent of the destruction of monuments, providing an antidote to the triumphalism and concomitant amnesia which in modern scholarship routinely present the 19th century as one of concern for the past. It charts the modernising impulse over several centuries, detailing the archaeological discoveries made (and usually destroyed) as walls were pulled down and town interiors re-planned, plus the brutal impact on landscape and antiquities as railways were laid out. Heritage was largely scorned, and identity found in modernity, not the past.

Readership

All interested in the survival and influence of the Roman past, attitudes towards it in 19th-century France, including the formation of museums, and debates over preservation and restoration of monuments.

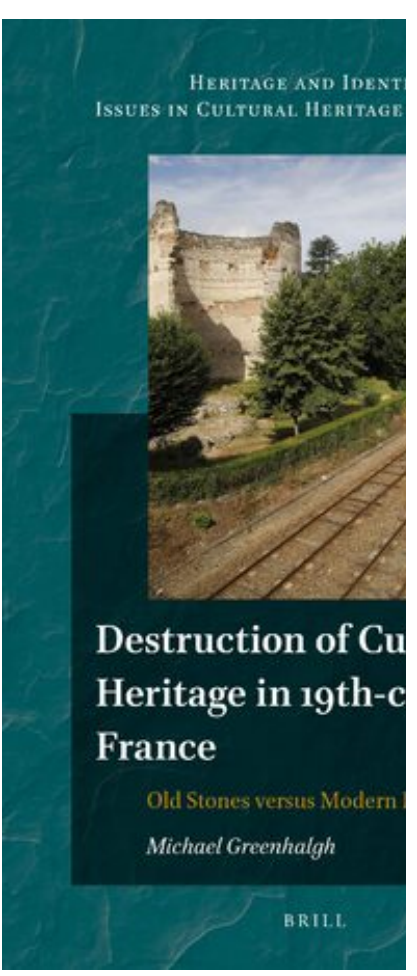

Pages: xiv, 462 pp.

Language: English

Subjects: Cultural Heritage ] Classical Studies, Archaeolo؛ Architecture, Classical Studi Warfare, History, Modern Hi

Publisher: Brill

Series: Heritage and Identity

E-Book (PDF)

Released online: 24 Aug 201!

ISBN: 978-90-04-29371-7

List price

USD \$227.00

Hardback

Publication date: o3 Sep 201

ISBN: 978-90-04-28920-8

List price

USD \$227.00 


\title{
Biographical Note
}

Michael Greenhalgh, PhD (1968), Emeritus Professor of Art History at the Australian National University, has published widely on the survival of the Roman world, most recently The Military and Colonial Destruction of the Roman landscape of North Africa (Leiden 2014).

For more information see brill.com

\author{
Order information: Order online at brill.com \\ +44330 3330049 | customerservices@brill.com \\ Submission information: brill.com/authors
}

Titles published by Brill | Fink, Brill | mentis or Brill | Schöningh: +49(o)715413279216| brill@brocom.de 
